\title{
Assimilation Organs of Plants and the Composition of their Stems
}

\author{
E. A. Ergasheva* and Kh. H. Kushiev \\ Khujand State University named after Academician B. Gafurov \\ Gulistan State University, Uzbekistan \\ *Corresponding author
}

\section{Keywords}

Assimilates,

Biomass, Genotype,

Photosynthesis,

Productivity,

Donor-acceptor

relations,

Attraction, Cotton,

Limiting and

unsaturated type of

branche

Article Info

Accepted:

22 March 2020

Available Online:

10 April 2020

A B S T R A C T

\section{Introduction}

When analyzing the patterns of crop formation, special attention is paid to the nature of the distribution and use of photosynthesis products for the growth and development of organs and parts of plants (Bagautdinova, 1971; Belikov, 1973; Obraztsov, 1981; Gifford., Evans, 1981; Kumakov, 1980; Nekrasova, 1988; Djanagoudar, 1989; Zamski, Schaffer, 1996; Bobojanova, 2007; Solieva, 2000; Saidov,
2004; Giyasidinov, 2007; Khuzhanazarova, 2007; Abdullaev et al., 2010a, b; Abdullaev et al., 2011; Pinkhasov and Nasyrov, 1965).

Features in the distribution of assimilants are one of the reasons for the large differences in the number of economic and biological crops in different genotypes and plant varieties. In this regard, we studied the distribution of assimilants in the organs of the plant and the attracting ability of cotton bolls. 


\section{Materials and Methods}

\section{Agroclimatic conditions of the venue}

Field experiments were conducted in 20082019 years at the experimental site of the Institute of Plant Physiology and Genetics of the Academy of Sciences of the Republic of Tajikistan (Rudaki region), located in the eastern part of the Gissar Valley at an altitude of $834 \mathrm{~m}$ above sea level. The climatic conditions of the test site are characterized by sharp seasonal fluctuations in temperature and air humidity. The average annual air temperature is $+14.20 \mathrm{C}$. The sum of effective temperatures (above 100C) is $4700-49000 \mathrm{C}$ (Agroclimatic resources of the Tajik SSR, 1976, part 1; Vladimirova, 1982). The average annual rainfall is $610 \mathrm{~mm}$ and their main amount (up to $90 \%$ ) falls on the winterspring period. The average annual relative humidity is $60 \%$. The total amount of incoming solar radiation per year is $7600 \mathrm{MJ} /$ $\mathrm{m} 2$, and photosynthetically active radiation (PAR) - $3200 \mathrm{MJ} / \mathrm{m}^{2}$. The soil of the experimental plot is brown-carbonate.

The objects of study were the varieties of fine-fiber cotton Gossypium barbadense L. Pima S-2, 23, and 504-B (spreading varieties of unspecified branching type) (Fig. 5) and 5595-B and 6465-B, 6249-B, 8386-B and 9326-B (varieties of the limiting branch type) (Fig. 6). Pima variety S-2 - AmericanEgyptian. The rest of all varieties are bred at the Vakhsh branch named after V.P. Krasichkov Institute of Agriculture of the Tajik Academy of Agricultural Sciences by Academicians V.P. Krasichkov, B.S. Sanginov and employees of the Institute. These varieties were kindly placed at our disposal by the academician of the Academy of Sciences of the Republic of Tajikistan B.S. Sanginov and the candidate of agricultural sciences A.S. Sanginov from the genetic collection of fine-fiber cotton of the Vakhsh branch named after V.P. Krasichkova Institute of Agriculture of the Tajik Academy of Agricultural Sciences (TASN). Morphobiological features and characteristics of economically valuable indicators of selection varieties of the Vakhsh branch of the Institute of Agriculture are described in detail in (Krasichkov, 1970; Sanginov, 1983; Sanginov and Samandarov, 1992). Characteristics of the Pima S-2 AmericanEgyptian variety are listed in the Catalog of the VIR World Collection Fine-Fibrous Cotton (Lemeshev et al., 1988).

\section{Results and Discussion}

\section{Distribution of assimilants by plant organs}

An analysis of the distribution of assimilants in plant organs during the ripening phase of the crop showed (Table 1) that in varieties of fine-fiber cotton with an unspecified branching type Pima S-2, 23, 504-B, 32-52\% of the dry above-ground biomass of the plant is composed of vegetative organs (mainly stem and leaves), and 40-45\% - reproductive organs. In more modern varieties 6465-B, 6249-B, 8386-B and 9326-B with zero branching type, the proportion of vegetative organs in the total dry mass of the plant is 52$54 \%$, and the dry mass of fruit organs is 46$48 \%$. The mass of raw cotton in the total dry plant biomass (yield index) in old varieties is $21-22 \%$, and in modern varieties - 35-42\%. These data clearly show that, as a result of a hundred-year-old selection of fine-fiber cotton varieties, the yield index for this crop increased significantly - from 0.21 for PimaS-2 to 0.42 for $9326-\mathrm{B}$ (Tables 1 and 2). This is due to the fact that in varieties of later breeding, the main number of assimilants was mainly directed to the formation of cotton fiber and seeds.

Similar results were obtained when studying the distribution of assimilants in ancient and 
modern varieties of medium fiber cotton of various cultivars (Abdullaev and Karimov, 2007). When analyzing the distribution of dry weight among plant organs during the ripening phase of the crop, it was shown that in the old varieties Pakhtakor-36 M2 (second cultivar) and C460 (third cultivar), vegetative organs comprise $34-35 \%$ of the dry aboveground biomass of the plant, and $65-66 \%$ generative organs. In more modern varieties 108-F, S-4727 (fourth grade), Tashkent-1 (fifth grade) and $175-\mathrm{F}$ (sixth grade), the proportion of vegetative organs in the total phytomass is $25-27 \%$, and the dry weight of fruit organs is $73-75 \%$. The mass of raw cotton in the total dry mass of the plant of ancient varieties was $35-49 \%$, and in modern varieties $-51-57 \%$.

These data also clearly show that in varieties of later breeding, the main amount of photoassimilates is mainly spent on the formation of cotton fiber and seeds.

According to (Wells, Meredith, 1984; Meredith, Wells, 1989), a comparative analysis of the ratio of the mass of vegetative and reproductive organs in varieties of medium-fiber cotton bred and zoned in the United States for 70 years (1905-1976) revealed that in old varieties (zoned before 1920), assimilants were most directed to the stem, and in modern varieties (zoned after 1950), to the reproductive organs. So, the total dry mass of the stem in the old cultivar Lone Star, which was zoned in 1905. amounted to $705 \mathrm{~g} / \mathrm{m} 2$, and in the variety STV 825 of later breeding and zoned in 1978 $-515 \mathrm{~g} / \mathrm{m} 2$.

According to the results of studies conducted at the Institute of Agriculture of the Tajik Academy of Agricultural Sciences in 20142015, the majority of hybrid combinations obtained by crossing in the fruiting phase had the largest total dry weight of the plant was
400.3-422.7 g. accounted for by the most important assimilating organs - the main stem, fruit branches, leaves and green capsules (Saidov and Dragavtsev et al., 2019).

Thus, based on our results of studying the distribution of dry biomass among plant organs in varieties of fine-fiber cotton with a limit and unspecified type of fruit branches, it can be argued that an increase in cotton yield over a hundred-year-old selection (19132013) - when new highly productive varieties are bred with high adaptive properties and potentials of resistance to diseases, pests and extreme environmental factors was achieved due to a change in the direction of the distribution In assimilated within bush cotton in favor of fruit bodies, and not by raising the rate of photosynthesis.

However, it should be noted that this statement does not in any way discredit the dominant role of photosynthesis in the production process. The results of our studies convince us that the analysis of the regulation of photosynthesis and the mechanisms of donor - acceptor relations in plants should be of paramount importance in breeding work.

\section{Appealing ability of buds}

Attraction is the most important property of plants to actively entice soft substances to the centers of growth processes, including to growing (after the fertilization of the egg) seeds and fruits. Such a feature, economically important for cultivated plants, as the size (mass) of the ripened fruit, in particular cotton bolls, depends on the level of attraction (Karimov and Abdullaev, 2008). At one time, R.F. Saidov studied the polymorphism of the genetic systems of attraction, microdistribution of assimilants and adaptability in different cotton genotypes and found that the variability limits of the studied physiological and genetic systems vary 
depending on the cotton cultivation zone and weather conditions of the year. For each region, selection for improving the basic physiological and genetic systems should be based on different donors, since in different ecological environments the number and set of genes that determine valuable economic traits of plants change (Saidov, 2011).

Different varieties of the same type of cotton differ significantly in the level of attraction and the use of assimilates for the growth and development of fruit organs, which leads to different sizes of bolls (the mass of raw cotton in one box) under the same agroecological conditions. Cotton cultivars with a high attracting ability have great potential for producing a good, high quality crop. Therefore, to solve a number of theoretical and applied problems of selection, the quantitative determination of the value of the attracting ability of the fruit organs of plants and the degree of its differences due to genotypic and phenotypic factors are important.

The absorbing ability of cotton bolls is realized during the period of growth of the biomass of bolls - from the beginning of the budding phase to the phase of full maturation.

The results of the analysis of the attracting ability of fruits (bolls) in varieties of finefiber cotton with a limiting and unsaturated branching type are presented in Table 3. As can be seen from these data, different varieties of the same type of cotton $G$. barbadense $L$. differing in the type of branching are characterized by a significant difference in the level of attraction of photosynthesis products, which leads to different sizes of boxes (the mass of raw cotton in one box) when they are grown under the same agrotechnical conditions. So, in the ancient Pima variety S-2 with unspecified type of fruit branches and modern grade 9326-B with zero branching type, the highest integral attracting ability of the boll is observed (18.36 and 17.13, respectively) and, accordingly, a large mass of raw cotton in one boll (3.65 and $3.79 \mathrm{~g}$, respectively). In grade 5595-B, the smaller attractive power of the capsule (10.25) also caused the smaller size of the capsule $(2.51 \mathrm{~g})$. This genotypic difference indicates the hereditary nature of the trait "attracting box strength" in cotton.

Table.1 Technological qualities of fiber of fine-fiber cotton varieties with ultimate and unspecified fiber types, 2015-2018 years

\begin{tabular}{|c|c|c|c|c|c|c|c|}
\hline $\begin{array}{c}\text { Type of } \\
\text { branching } \\
\text { of a bush of } \\
\text { cotton }\end{array}$ & Sort & $\begin{array}{c}\text { Staple length, } \\
\text { mm }\end{array}$ & $\begin{array}{l}\text { Breaking } \\
\text { load, gs / } \\
\text { tex }\end{array}$ & $\begin{array}{c}\text { Metric } \\
\text { number, } \\
\text { tex }\end{array}$ & $\begin{array}{l}\text { Breaking } \\
\text { length, km }\end{array}$ & $\begin{array}{c}\text { Coefficient } \\
\text { fiber } \\
\text { maturity }\end{array}$ & $\begin{array}{c}\text { Fiber } \\
\text { type }\end{array}$ \\
\hline \multirow{3}{*}{$\begin{array}{l}\text { Unlimited } \\
\text { Spreading }\end{array}$} & Пима S-2 & $40.0(0.0)$ & $4.7(0.0)$ & $7520(+260)$ & $35.3(+1.4)$ & $2.1(+0.1)$ & II \\
\hline & 23 & $40.0(0.0)$ & $4.8(+0.1)$ & $7400(+140)$ & $35.3(+1.4)$ & $2.0(0.0)$ & II \\
\hline & 504-B & $41.0(+1.0)$ & $4.8(+0.1)$ & $7070(-190)$ & $33.9(-0.2)$ & $2.0(0.0)$ & II \\
\hline \multirow{5}{*}{$\begin{array}{l}\text { Limited } \\
\text { Compact }\end{array}$} & 5595-B & $39.0(-1.0)$ & $4.6(-0.1)$ & $6800(-460)$ & $31.3(-2.8)$ & $2.0(0.0)$ & II \\
\hline & 6249-B & $40.0(0.0)$ & $4.75(0.0)$ & $6990(-210)$ & $33.2(-1.2)$ & $2.0(0.0)$ & II -III \\
\hline & $6465-B$ & $40.0(0.0)$ & $4.9(+0.2)$ & $6710(-550)$ & $32.9(-1.2)$ & $2.1(+0.1)$ & III \\
\hline & 8386-B & $40.5(+0.5)$ & $4.7(0.0)$ & $7280(+20)$ & $34.2(+0.1)$ & $2.0(0.0)$ & II \\
\hline & $\begin{array}{c}\text { 9326-В } \\
\text { ст. }\end{array}$ & 40.0 & $4.7(0.0)$ & $7520(+260)$ & $35.3(+1.4)$ & $2.0(0.0)$ & II \\
\hline
\end{tabular}


Table.2 Distribution of dry biomass by plant organs in varieties of fine fiber cotton with different types of branching, Ripeningphase, 2015-2018 years

\begin{tabular}{|c|c|c|c|c|c|c|c|c|c|c|c|}
\hline \multirow{2}{*}{$\begin{array}{c}\text { Type of } \\
\text { branching } \\
\text { of a bush of } \\
\text { cotton }\end{array}$} & \multirow[b]{2}{*}{ Sort } & \multicolumn{8}{|c|}{ Dry mass of organs and parts of the plant, $g$} & \multirow{2}{*}{$\begin{array}{c}\text { Total } \\
\text { biomass } \\
\text { of the } \\
\text { plant, } g\end{array}$} & \multirow{2}{*}{$\begin{array}{c}\text { Total } \\
\text { biomas } \\
\text { s of the } \\
\text { plant, } g\end{array}$} \\
\hline & & Stem & Leaves & $\begin{array}{c}\text { Petiolesof } \\
\text { leaves }\end{array}$ & $\begin{array}{c}\text { Fruit } \\
\text { branches }\end{array}$ & Ovary & $\begin{array}{l}\text { Green } \\
\text { buds }\end{array}$ & Open buds & $\begin{array}{l}\text { Mass of } \\
\text { cotton } \\
\text { sed } 1 \\
\text { plant }\end{array}$ & & \\
\hline \multirow{3}{*}{$\begin{array}{l}\text { Limited } \\
\text { Compact }\end{array}$} & $\begin{array}{l}\text { Пима } \\
\text { S-2 }\end{array}$ & $35.9 \pm 3$ & $24.9 \pm 2.2$ & $3.5 \pm 0.3$ & $\begin{array}{c}17.9 \pm 1 \\
6\end{array}$ & $0.9 \pm 0.07$ & $56.7 \pm 5.1$ & $17.2 \pm 1.4$ & $42.1 \pm 3.4$ & $199 \pm 11$ & 0.21 \\
\hline & 23 & $15.6 \pm 1$ & $13.2 \pm 1.0$ & $1.7 \pm 0.2$ & $8.4 \pm 0.8$ & $0.5 \pm 0.04$ & $28.0 \pm 2.5$ & $6.5 \pm 0.5$ & $17.7 \pm 1.6$ & $91.7 \pm 4.6$ & 0.19 \\
\hline & 504-B & $16.8 \pm 1$ & $9.8 \pm 0.72$ & $1.3 \pm 1.0$ & $8.6 \pm 0.8$ & $0.7 \pm 0.06$ & $46.1 \pm 4.2$ & $9.6 \pm 0.8$ & $21.8 \pm 2.1$ & $114.7 \pm 8$ & 0.19 \\
\hline \multirow{5}{*}{$\begin{array}{l}\text { Unlimited } \\
\text { Spreading }\end{array}$} & $5595-\mathrm{B}$ & $10.8 \pm 1$ & $11.3 \pm 1.1$ & $1.6 \pm 0.1$ & $4.7 \pm 0.4$ & $1.7 \pm 0.1$ & $24.0 \pm 1.9$ & $9.8 \pm 0.9$ & $25.0 \pm 2.2$ & $89.9 \pm 8.9$ & 0.28 \\
\hline & 6465-B & $8.8 \pm 1.8$ & $17.7 \pm 1.6$ & $2.5 \pm 0.2$ & $2.3 \pm 0.2$ & $0.3 \pm 0.02$ & $34.9 \pm 3.1$ & $11.5 \pm 1.0$ & $22.6 \pm 2.1$ & $100.6 \pm 9$ & 0.23 \\
\hline & 6249-B & $11.1 \pm 2$ & $11.6 \pm 2.8$ & $1.3 \pm 0.1$ & $2.5 \pm 0.2$ & $0.5 \pm 0.05$ & $24.6 \pm 2.4$ & $9.2 \pm 0.7$ & $32.9 \pm 2.3$ & $94.4 \pm 9.0$ & 0.35 \\
\hline & 8386-B & $8.71 \pm 1$ & $8.1 \pm 0.7$ & $1.2 \pm 0.1$ & $2.0 \pm 0.2$ & $1.6 \pm 0.14$ & $24.6 \pm 2.2$ & $6.2 \pm 0.5$ & $17.0 \pm 1.7$ & $69.6 \pm 5.5$ & 0.24 \\
\hline & 9326-B & $11.0 \pm 1$ & $13.3 \pm 0.3$ & $1.8 \pm 0.2$ & $2.0 \pm 0.2$ & $0.6 \pm 0.08$ & $11.6 \pm 0.6$ & $12.2 \pm 1.2$ & $37.7 \pm 3.7$ & $90.1 \pm 7.4$ & 0.42 \\
\hline
\end{tabular}


Table.3 Distribution of dry biomass by plant organs in varieties of fine fiber cotton with different types of branching. Ripeningphase. 2015-2019 years

\begin{tabular}{|c|c|c|c|c|c|c|c|c|c|c|c|}
\hline \multirow{2}{*}{$\begin{array}{c}\text { Type of } \\
\text { branching } \\
\text { of a bush } \\
\text { of cotton }\end{array}$} & \multirow[b]{2}{*}{ Sort } & \multicolumn{8}{|c|}{ Dry mass of organs and parts of the plant, $g$} & \multirow[b]{2}{*}{$\begin{array}{c}\text { Total } \\
\text { biomas } \\
\text { s of the } \\
\text { plant, } g\end{array}$} & \multirow{2}{*}{$\begin{array}{c}\text { Total } \\
\text { biomass } \\
\text { of the } \\
\text { plant, } g\end{array}$} \\
\hline & & Stem & Leaves & $\begin{array}{c}\text { Petioles of } \\
\text { leaves }\end{array}$ & $\begin{array}{c}\text { Fruit } \\
\text { branches }\end{array}$ & Ovary & Green buds & Open buds & $\begin{array}{c}\text { Mass of } \\
\text { cottonsed } 1 \\
\text { plant }\end{array}$ & & \\
\hline \multirow{3}{*}{$\begin{array}{l}\text { Unlimited } \\
\text { Spreading }\end{array}$} & $\begin{array}{l}\text { Пима } \\
\text { S-2 }\end{array}$ & $33.45 \pm 3.01$ & $28.96 \pm 1.7$ & $2.35 \pm 0.81$ & $18.93 \pm 1.71$ & $1.93 \pm 0.11$ & $27.9 \pm 1.61$ & $16.24 \pm 1.5$ & $37.58 \pm 3.38$ & $\begin{array}{c}167.34 \pm \\
16.11\end{array}$ & 22.4 \\
\hline & 23 & $21.24 \pm 1.91$ & $21.24 \pm 1.01$ & $1.4 \pm 0.12$ & $11.43 \pm 1.03$ & $1.53 \pm 0.14$ & $21.33 \pm 1.91$ & $11.07 \pm 0.99$ & $30.77 \pm 2.76$ & $\begin{array}{c}122.64 \pm \\
10.0\end{array}$ & 25.0 \\
\hline & $504-\mathrm{B}$ & $33.0 \pm 1.89$ & $15.0 \pm 1.35$ & $2.22 \pm 0.19$ & $19.7 \pm 1.32$ & $1.2 \pm 0.1$ & $21.26 \pm 1.91$ & $13.06 \pm 1.17$ & $34.35 \pm 3.1$ & $\begin{array}{c}139.94 \pm \\
12.05\end{array}$ & 24.6 \\
\hline \multirow{5}{*}{$\begin{array}{l}\text { Limited } \\
\text { Compact }\end{array}$} & 5595-B & $16.17 \pm 1.45$ & $7.44 \pm 0.66$ & $1.59 \pm 0.14$ & $10.63 \pm 1.98$ & $3.45 \pm 0.31$ & $10.15 \pm 0.91$ & $16.5 \pm 1.32$ & $31.4 \pm 2.3$ & $\begin{array}{c}97.33 \pm 8 \\
.42\end{array}$ & 32.2 \\
\hline & $6465-B$ & $16.28 \pm 1.48$ & $18.87 \pm 1.69$ & $2.96 \pm 0.26$ & $10.09 \pm 0.99$ & $1.24 \pm 0.11$ & $10.59 \pm 0.95$ & $13.4 \pm 1.2$ & $34.9 \pm 3.13$ & $\begin{array}{c}108.33 \pm \\
9.85\end{array}$ & 32.2 \\
\hline & 6249-B & $17.85 \pm 1.69$ & $11.17 \pm 1.12$ & $2.09 \pm 0.2$ & $11.33 \pm 1.14$ & $2.75 \pm 0.22$ & $9.5 \pm 0.76$ & $10.78 \pm 0.96$ & $33.5 \pm 2.74$ & $\begin{array}{c}95.97 \pm 8 \\
.64\end{array}$ & 34.9 \\
\hline & 8386-B & $20.5 \pm 1.84$ & $12.67 \pm 1.14$ & $2.35 \pm 0.18$ & $11.05 \pm 0.97$ & $1.45 \pm 0.13$ & $11.15 \pm 1.0$ & $9.35 \pm 0.84$ & $34.8 \pm 2.14$ & $\begin{array}{c}103.32 \pm \\
8.36\end{array}$ & 33.7 \\
\hline & 9326-B & $14.57 \pm 1.36$ & $12.4 \pm 0.98$ & $1.66 \pm 0.15$ & $10.12 \pm 1.01$ & $0.65 \pm 0.15$ & $12.36 \pm 1.11$ & $11.78 \pm 1.10$ & $34.93 \pm 3.14$ & $\begin{array}{c}98.47 \pm 8 \\
.86\end{array}$ & 35.5 \\
\hline
\end{tabular}


Table.4 Reflection of the state of the stem in different branched fine-fiber varieties of cotton. 2015-2018 years

\begin{tabular}{|c|c|c|c|c|c|c|c|}
\hline \multirow{2}{*}{$\begin{array}{c}\text { Type of } \\
\text { branching of a } \\
\text { bush of cotton }\end{array}$} & \multirow[t]{2}{*}{ Sort } & \multicolumn{2}{|c|}{$\begin{array}{l}\text { The dry weight of the whole bud } \\
\text { in phase }\end{array}$} & \multirow{2}{*}{$\begin{array}{l}\text { The mass of } \\
\text { raw cotton in } \\
\text { one bud, } g\end{array}$} & \multirow{2}{*}{$\begin{array}{l}\text { Appealing feature } \\
\text { of the bud ( } \mathrm{K} \\
\text { ripening / } \mathrm{K} \\
\text { flowering). The } \\
\text { amount of } \\
\text { emergence of a bud }\end{array}$} & \multirow{2}{*}{$\begin{array}{l}\text { The amount of } \\
\text { reflection } \\
\text { (consideration) of } \\
\text { cotton in one bud }\end{array}$} & \multirow{2}{*}{$\begin{array}{c}\text { Cotton } \\
\text { harvest, g / } \\
\text { plant }\end{array}$} \\
\hline & & Blossoming & Ripening & & & & \\
\hline \multirow{3}{*}{$\begin{array}{l}\text { Unlimited } \\
\text { Spreading }\end{array}$} & PimaS-2 & $0.271 \pm 0.027$ & $4.93 \pm 0.45$ & $3.65 \pm 0.38$ & $18.36 \pm 1.18$ & $13.62 \pm 0.89$ & $42.1 \pm 3.4$ \\
\hline & 23 & $0.263 \pm 0.023$ & $4.19 \pm 0.30$ & $2.96 \pm 0.015$ & $16.14 \pm 0.88$ & $11.43 \pm 0.80$ & $17.7 \pm 1.6$ \\
\hline & 504-B & $0.270 \pm 0.22$ & $3.90 \pm 0.17$ & $2.83 \pm 0.11$ & $14.54 \pm 0.52$ & $10.98 \pm 0.21$ & $21.8 \pm 2.1$ \\
\hline \multirow{5}{*}{$\begin{array}{l}\text { Limited } \\
\text { Compact }\end{array}$} & 5595-B & $0.340 \pm 0.035$ & $3.48 \pm 0.35$ & $2.51 \pm 0.25$ & $10.25 \pm 0.27$ & $7.44 \pm 0.22$ & $25.0 \pm 2.2$ \\
\hline & $6465-B$ & $0.240 \pm 0.016$ & $3.59 \pm 0.32$ & $2.51 \pm 0.28$ & $14.97 \pm 1.13$ & $10.49 \pm 1.00$ & $22.6 \pm 2.1$ \\
\hline & 6249-B & $0.283 \pm 0.020$ & $4.20 \pm 0.11$ & $2.86 \pm 0.94$ & $15.32 \pm 1.43$ & $10.44 \pm 1.00$ & $32.9 \pm 2.3$ \\
\hline & 8386-B & $0.256 \pm 0.02$ & $3.19 \pm 0.14$ & $2.21 \pm 0.15$ & $13.67 \pm 1.14$ & $9.37 \pm 0.86$ & $17.0 \pm 1.6$ \\
\hline & 9326-B & $0.311 \pm 0.015$ & $5.32 \pm 0.26$ & $3.79 \pm 0.17$ & $17.13 \pm 0.44$ & $12.22 \pm 0.31$ & $37.7 \pm 3.7$ \\
\hline
\end{tabular}


There is a close positive relationship between the integral attracting ability of the buds and their mass $(r=0.785 \pm 0.01)$, i.e. the higher the attractiveness of the buds, the greater the mass of raw cotton in the bud. Among the studied genotypes of the Pima variety, S-2 (the ancient variety) and 9326-B (a more modern variety) had the best physiological and genetic attraction system.

Since the main driving forces of attraction in a growing boll are the processes of receipt of the transported product of photosynthesis sucrose and phosphorylated hexoses - as well as the synthesis of cellulose in the fiber, we also calculated the level of attraction for the mass of raw cotton in one bud (Table 4). As a result, data were obtained confirming the above patterns.

Thus, the results of our studies showed that the potential for the formation of a high yield of good quality is more favorable for genotypes - cotton varieties, which have a higher attracting ability of bolls (Pima varieties $\mathrm{S}-2$ and 9326-B).

This indicates that the determination of the attracting ability of the bolls and the degree of its differences depending on the genotype of the variety and environmental factors is important for solving practical problems of cotton breeding.

In conclusion, an analysis of the distribution and accumulation of dry mass among plant organs in varieties of fine-fiber cotton with various types of fruit branches allows us to make the following conclusion.

The studied varieties of fine-fiber cotton with the limiting and unsaturated types of sympodial branches were very different from each other both in the distribution of assimilates and in the accumulation of dry mass over plant organs. In turn, these differences were the reason for the formation of a different biological and economic crop of varieties.

It was established that in varieties of later breeding with the limiting type of fruit branches, the majority of assimilates were mainly directed to the formation of cotton fiber and seeds. This was facilitated by the attracting ability of the growing box fruit. It was revealed that the modern grade 9326-B with zero branching type has the highest integral attracting ability of the box and, accordingly, it has a large mass of raw cotton of one box.

During defoliation, when the capsules are left without the main donor of leaf assimilates, the rate of $\mathrm{CO}_{2}$ assimilation of non-leaf organs, the capsules with bracts, increases (the total potential photosynthesis rate increases and amounts to $30-33 \mathrm{mg} \mathrm{CO} / \mathrm{g}$ dry matter per hour from the total potential photosynthesis of plants). If photosynthesis of bracts and capsules does not cover the total need of attracting centers - fruit organs, then the plant will be forced to use (mobilize) part of the substances accumulated (deposited) in the vegetative organs, in particular in the stem (Dadoboeva et al., 2015). As a result, during the ripening phase, the mass of the stem decreases

Increasing the adaptive potential of cotton, i.e. the creation of heat and drought tolerant varieties depends largely on studying the interaction of the genotype and the environment, identifying physiological, morphological and genetic mechanisms that provide adaptive abilities for elevated temperature, lack of soil moisture and on the search for donors for drought tolerance among the existing assortment of varieties, lines, foreign samples, introduced hybrid populations created with the participation of wild diploid and tetraploid species with 
unique resistance genes of them in the selection process.

In this regard, the physiological characteristics of plants contribute to the identification of a number of complex traits that determine a new form or variety with respect to its productivity and resistance to adverse environmental factors, in particular, to conditions of temperature and water stress (Safarova, 2018).

Summarizing the foregoing, we can conclude that in the last years of the 20th century, an increase in the yield of fine-fiber cotton was achieved as a result of the selection of new highly productive varieties with zero branching type, due to the selection change in the bush habit and the nature of the distribution of photosynthesis products in favor of fruit organs.

Nevertheless, it must be remembered that climate change and the ecological balance of nature, adverse weather events in the spring and autumn months (continuous rainfall, rain and hail, low temperatures and precipitation) lead to the impossibility of timely adherence to agrotechnology of growing cotton and have a negative impact on quality and the amount of harvest (Dzhumaev, 2017). Since the international demand for cotton fiber and textiles is growing from year to year, it is advisable to produce and sow precocious varieties of cotton, which allow to obtain high-quality products that meet international requirements.

\section{Acknowledgement}

The instrument base of the Institute of Botany, Physiology and Plant Genetics of the Academy of Sciences of the Republic of Tajikistan, Tajik Agrarian University (Dushanbe) was used in the work.
Field experiments were carried out in 20152019. at the experimental site of the Institute of Botany, Physiology and Plant Genetics of the Academy of Sciences of the Republic of Tajikistan (Rudaki region), located in the eastern part of the Gissar Valley.

I express gratitude to the supervisor of studies, Doctor of Biological Sciences Kh.Kh. Kushiev (GulSU, Uzbekistan), Corresponding Member of the Academy of Sciences of the Republic of Tajikistan Kh. Abdullaev, Academician of the Academy of Sciences of the Republic of Tajikistan Kh. Karimov for their recommendation and advice.

\section{References}

Ablullaev, Kh.A, Bobodjonova M.D., Giyasiddinov B.B., Solieva B.A., (2011). Monography: Photosynthesis and donor-acceptor relations in cotton. Khujand: Meroj,-176p.

AblullaevKh.A, KarimovKh.Kh. (2007) IzmneniypokazateliyfotosintezaАбдулл аевX.А., КаримовХ.X. (2007) Changes in photosynthesis, donor-acceptor relationships, and productivity in the process of long-term selection of new varieties of cotton. Journal of Academy of Sciences of the Republic of Tajikistan. Department of Biological Sciences №4 (161), 31-39.

Ablullaev Kh.A, KarimovKh.Kh., Giyasiddinov B.B., Solieva B.A., Mirakilov Kh.M., Saidnabiev M.M. (2010) Daily and seasonal dynamics of photosynthesis intensity and yield of varieties of fine-fiber cotton of various cultivars. Journal of Academy of Sciences of the Republic of Tajikistan. Department of Biological Sciences.№3 (172), 8-17.

Bagautdinova R.I. (1971) Relationship between photosynthesis rate, assimilate distribution and productivity in soybean 
and potato varieties. Photosynthesis and use of solar energy. - L.: Nauka, - 116122.

BelikovI.F. (1973) The main laws of transport and distribution of assimilates in agricultural plants. Proceedings of the Biological and Soil Institute, Far Eastern Scientific Center, Academy of Sciences of the USSR. Assimilate transport and stockpiling of substances. - Vladivostok, № 20 (123), 154-160.

Bobodjonova M.D. (2007) Photosynthesis, donor-acceptor relations, and productivity of medium fiber cotton (Gossypium hirsutum L.). Author's abstract. Diss. Doctor of Biological Sciences / AN RT, Institute of Plant Physiology and Genetics. - Dushanbe, $23 \mathrm{c}$

\section{Dadboeva M.A., Giyasiddinov B.B.,} Mirakilov Kh.M., Solieva B.A., Abdullaev Kh.A. (2015) The role of leaves in the formation of technological qualities of cotton fiber. Reports of the Academy of Sciences of the Republic of Tajikistan, V.58.-№2, 161-166.

Djongaudar B.S. (1989) Photosynthesis and productivity of cotton in connection with the phenomenon of heterosis. Thesis Ph.D. in Biology. - Dushanbe, $118 \mathrm{c}$.

Dzumaev Sh.B. (2017) Productivity and technological indicators of precocious mid-fiber lines of cotton. International Agricultural Journal, №5, 38-39.

Gifford R.M., Evans L.T. (1981) Photosynthesis, carbon partitioning, and yield. Ann. Rev. Plant Physiol., 32, 485509.

Giyasiddinov B.B. (2007)Indicators of photosynthesis and donor-acceptor relations in different cotton genotypes in fruiting modeling: Author's abstract ... C and. Biol. Science / AN RT, Institute of Plant Physiology and Genetics. - Dushanbe,-23 c.
Karimov Kh.Kh., Ablullaev Kh.A (2008) The limits of the variability of the mass of raw cotton in one box in different genotypes of cotton. Tajikistan Academy of Sciences reports, V. 51, №1, 69-73.

Khujanazarova M.I. (2007) Agrotechnical indicators and their role in the attracting abilities of cotton in the conditions of Northern Tajikistan: Abstract of thesis Ph.D. - Dushanbe, - 23 c.

Kumakov B.A. (1980) Correlative relations between plant organs in the process of crop formation. Plantphysiology, V.27, № 5, 975-984.

Meredith J.W.R., Wells R. (1989) Potential for increasing cotton yields through enhanced partitioning to reproductive structures. Crop Science, 29, №3, 636639.

Nekrasova G.F. (1988) The structural and functional organization of the photosynthetic system and the production process in different wheat genotypes. Photosynthesis and production process. - Sverdlovsk, -3139.

Obraztsov A.S. (1981) Biological basis of plant breeding. - M .: Kolos,-271 c.

Pinkhasov Yu. I. and Nasirov $\mathrm{Yu}, \mathrm{S}$. (1965)Purposeful use of assimilates as a factor in increasing the yield of cotton. Plant physiology - agriculture. Dushanbe, - 81-94.

Safarova S.S. (2018) Physiological and biochemical characteristics of promising varieties of fine-fiber cotton grown in the Vakhsh valley. Diss. Ph.D. - Dushanbe, - 137 c.

Saidov S.T. (2004) Cotton selection by photosynthetic test signs in combination with traditional selection methods: Thesis of Doctor of chemical sciences. Dushanbe,-320c.

Saidov S.T. (2011) Ecological and genetic analysis of attraction systems, 
microdistribution of assimilates and adaptability in cotton and identification of valuable donors for selection. Abstract. diss candidate of agricultural sciences - Dushanbe, - 23 c.

Saidov S.T., Dragavtsev V.A., Sadikov A.T. (2019). Distribution of dry biomass by organs of cotton plants in the fruiting phase. Agricultural technology. release. 1, №3, 11-16.

Solieva B.A. (2000). The relationship between assimilating and reproductive organs in cotton: Diss. PhD Biol. Dushanbe,-142p.

Wells R., Meredith J.W.R. (1984). Comparative growth of obsolete and modern cotton cultivars. I. Vegetative dry matter partitioning. Crop Science, 24, №5, 858-862.

Zamski E., Schaffer A.A. (eds) (1996). Photoassimilate distribution in plants and crops. Source-sink relationships. New York: Marcel Dekker, -836p.

\section{How to cite this article:}

Ergasheva, E. A. and Kushiev, Kh. H. 2020. Assimilation Organs of Plants and the Composition of their Stems. Int.J.Curr.Microbiol.App.Sci. 9(04): 2645-2655.

doi: https://doi.org/10.20546/ijcmas.2020.904.316 